\title{
Effect of Salt on the Growth and Metabolism of Glycine max
}

\author{
Helena Müller Queiroz ${ }^{1}$, Ladaslav Sodek ${ }^{2}$ and Claudia Regina Baptista Haddad ${ }^{2 *}$ \\ ${ }^{1}$ Laboratório Nacional Agropecuário; Rua Raul Ferrari, s/n; 13100-105; Campinas - SP - Brasil ${ }^{2}$ Departamento de \\ Biologia Vegetal; Instituto de Biologia; Universidade Estadual de Campinas; C. P.: 6109; 13083-862; Campinas - \\ SP - Brasil
}

\begin{abstract}
Soybean plants cultivated with 50, 100 and $200 \mathrm{mM}$ of $\mathrm{NaCl}$, revealed that root growth was less affected by salinity than shoots. Salinity led to a reduction in leaf area and an increase in water content of the roots. These factors could contribute to the adaptation of the plant, improving its hydration. Although nitrate and free amino acid levels were reduced by salt treatment in roots, protein content of leaves was not altered. Salinity led to alterations in xylem amino acid composition, with increases in Ser, Ala, Gaba and Pro and a decrease in Asn. Similar changes were seen for Asn and Ser in roots together with a much stronger increase in Gaba. It is suggested that the decline in Asn reflects its conversion to Ala and Gaba (via Glu) in the roots while the increase in Pro and Gaba could be related to the adaptation of the plant to salinity.
\end{abstract}

Key words: soybean, stress, amino acid transport, asparagine, alanine, $\gamma$-aminobutyrate

\section{INTRODUCTION}

Salinization of soil affects approximately $20 \%$ of the world's agricultural land (FAO 2000). Salinity affects the dry and fresh mass (Tabatabaei 2006; Blanco et al. 2008; Demir and Mazi 2008) the development and the productivity of cultivated species (Neto and Nogueira 1999; Kaya et al. 2007; Zheng et al. 2008; Türkan and Demiral 2009, Galvan-Ampudia and Testerink 2011).

Reduction in the growth rate of the leaf can represent an adaptation to salt stress, since increased levels of salts in the soil impedes the uptake of water by the plant (Carillo et al. 2005) and the reduction in leaf area limits transpiration (Neumann 1997). Another adaptation to salinity is the increase in succulence, which reduces the concentration of salts in the protoplasm (Ghoulam et al. 2002). The greater growth of the roots in comparison with the aerial part is also considered an adaptation to saline stress (Alshamary et al. 2004) since it results in an increased surface area for water uptake, thereby preventing dehydration (Okusanya 1977).

Salinity reduces the uptake and transport of nitrate (Carillo et al. 2005; Surabhi et al 2008; MaaroufiDguimi et al. 2011) and, consequently, the assimilation of nitrogen necessary for protein synthesis (Silveira et al. 2001; 2003; Qu et al. 2011).

Abiotic stresses alter the form and concentration of amino acids transported in plants (Souza and Sodek 2003; Renault et al. 2010). Under salt stress an accumulation of Asn (Ashraf and Harris 2004) and Gaba were observed (Bolarín et al. 1995)

Reactive oxygen species (ROS) are commonly produced in the cell and can act as signals in several transcription pathways, leading to altered patterns of gene expression which allow the plant to adjust adequately to the environment (Dutilleul

*Author for correspondence: chaddad@unicamp.br 
et al. 2003; Foyer and Noctor 2005a; 2005b; Gratão et al. 2005; Noctor 2006; Mhamdi et al. 2010; Queval et al. 2011). However, stress can result in an increase in ROS, causing the oxidation of lipids, proteins and DNA, thereby compromising the growth of the plant (Dutilleul et al. 2003; Foyer and Noctor 2005a; Gratão et al. 2005; Gomes-Júnior et al. 2007). Some studies have indicated that Pro may act as a scavenger of ROS (Vicente et al. 2004) and can stabilize membranes during salt stress (Hasegawa et al. 2000). Its accumulation has been related to an increase in tolerance to salt stress (Kaya et al. 2007). Another role attributed to Pro is as an osmolyte, permitting the plant to adjust osmotically under salinity (Hasegawa et al. 2000). Nevertheless, its role in the osmotic adjustment of plants cultivated under salinity can vary from species to species (Silveira et al. 2003; Misra and Gupta 2005).

Brazil has salinized soils in $11 \%$ of its territory, which is equivalent to an estimated area of 90 million ha (FAO 2000). Brazil is one of the world's leading soybean producers. According to a USDA (2005) report, Brazilian soybean production was estimated at 60 million tons for the $2005 / 2006$ crop. Soybean is considered to be moderately tolerant to salt stress (An et al. 2001). Nonetheless, there is a great diversity of responses among cultivars to salinity (Lee et al. 2004).

In this study soybean plants were used with the objective of determining the effects of salt on growth and metabolism together with an evaluation of the measured parameters as to their possible relationship with the adaptation of the plant to salinity.

\section{MATERIALS AND METHODS}

\section{Plant material and growth conditions}

Soybean plants, Glycine $\max$ (L.) Merr., cv. IAC 17, were cultivated without inoculation under natural conditions of light and temperature (23- $29{ }^{\circ} \mathrm{C}$ ), for 45 days, in the greenhouse. The mean maximum and minimum relative humidity over the experimental period was $97.9 \%$ and $54.3 \%$, respectively. The plants were grown in 1.5 $\mathrm{L}$ pots containing perlite and irrigated with tap water up to the V1 stage (Fehr et al. 1971). From then on they were given $250 \mathrm{~mL}$ of a complete nutrient solution (Hoagland and Arnon 1938) twice per week. In order to avoid osmotic shock,
$\mathrm{NaCl}$ was added to the nutrient solution in gradually increasing concentrations (Hasegawa et al. 2000), until the final concentrations of $50 \mathrm{mM}$, $100 \mathrm{mM}$ and $200 \mathrm{mM}$ were reached. The roots were assured a uniform distribution of the applied salt by placing the perforated pots with the plants inside similar non-perforated pots. This allowed the solution to rise by capillarity up the inner pot containing the plants, such that about $1 \mathrm{~cm}$ of nutrient solution remained in the outer pot. In order to avoid the accumulation of salt, immediately before the next salt application the substrate was washed and the external pot temporarily removed to allow complete drainage of the washed substrate.

\section{Growth measurements}

Measurements were taken of the length of the main root and shoot. Leaf area was determined using a LI-COR, model LI-3100. After fresh weight measurements, the roots, stems and leaves were dried in an oven at $80^{\circ} \mathrm{C}$, for 72 hours, and weighed. The water content was calculated by subtracting the dry weight from the fresh weight value and then dividing by the dry weight.

\section{Protein determination in leaves}

Samples of fully expanded leaves were ground to a powder under liquid nitrogen and extracted with $0.1 \mathrm{~N} \mathrm{NaOH}$ for $24 \mathrm{~h}$. The extract was centrifuged at $1,200 \mathrm{xg}$, for five min and the supernatant used for the assay of proteins (Bradford 1976).

\section{Extraction and assay of nitrate and amino acids from roots}

The harvest, preparation and extraction of root material were carried out as described by Souza and Sodek (2003). Nitrate was determined by the method of Cataldo et al. (1975) and total free amino acids according to Yemm and Cocking (1955)

\section{Separation and analysis of xylem sap amino acids by HPLC}

Amino acids were separated by reverse phase HPLC, using o-phthaldialdehyde (OPA) derivatives, as described previously by Puiatti and Sodek (1999). Since proline does not form a derivative with OPA, this amino acid was analyzed by a different HPLC system using FMOC-Cl derivatives (Nasholm et al 1987) with minor modifications, as described by Marur et al. (1994). 


\section{Experimental design and data analysis}

Treatments were completely randomized, using 10 replicates per treatment, where each pot with two plants represented a replicate. Data were submitted to an analysis of variance and, when $F$ was significant, means were compared by the Tukey test at the $5 \%$ probability level.

\section{RESULTS}

\section{Effect of salinity on growth}

Salinity did not alter the length of the root of the soybean plants, but the height of the shoot was reduced by up to $34 \%$ for plants receiving $200 \mathrm{mM}$ $\mathrm{NaCl}$, compared to the control (Table 1). A gradual reduction in leaf area was observed with the increase in salinity. This attained $57 \%$ in the treatment with $200 \mathrm{mM}$ of salt. The fresh weight of leaves and stems showed expressive reductions with increasing concentrations of $\mathrm{NaCl}$ in the medium but remained constant in the roots. The dry weights of leaf, stem and roots were also reduced in relation to the control with increasing salinity. The greatest reduction (62\%) occurred in the stems, for the $200 \mathrm{mM}$ treatment. No significant differences were observed in the water content of the aerial part of plants treated with salt compared to the control. However, the water content of the roots increased significantly in the presence of salt (Table 1).

Table 1 - Growth measurements of soybean plants, after receiving complete nutrient solution with different $\mathrm{NaCl}$ concentrations.

\begin{tabular}{lrrrr}
\hline \multirow{2}{*}{ Analysis } & \multicolumn{4}{c}{ NaCl concentration $\mathbf{( m M})$} \\
\cline { 2 - 5 } & $\mathbf{0}$ & $\mathbf{5 0}$ & $\mathbf{1 0 0}$ & \multicolumn{1}{c}{$\mathbf{2 0 0}$} \\
\hline Root length $(\mathrm{cm})$ & $31.40 \mathrm{a}$ & $28.60 \mathrm{a}$ & $24.10 \mathrm{a}$ & $26.40 \mathrm{a}$ \\
Shoot length $(\mathrm{cm})$ & $83.60 \mathrm{a}$ & $70.60 \mathrm{ab}$ & $62.00 \mathrm{bc}$ & $55.20 \mathrm{c}$ \\
Leaf area $\left(\mathrm{cm}^{2}\right)$ & $574.64 \mathrm{a}$ & $426.46 \mathrm{~b}$ & $327.59 \mathrm{bc}$ & $246.66 \mathrm{c}$ \\
Leaf fresh mass $(\mathrm{g})$ & $5.00 \mathrm{a}$ & $3.67 \mathrm{ab}$ & $3.17 \mathrm{~b}$ & $2.50 \mathrm{~b}$ \\
Shoot fresh mass $(\mathrm{g})$ & $4.95 \mathrm{a}$ & $3.76 \mathrm{ab}$ & $3.13 \mathrm{bc}$ & $2.55 \mathrm{c}$ \\
Root fresh mass $(\mathrm{g})$ & $3.70 \mathrm{a}$ & $3.51 \mathrm{a}$ & $2.65 \mathrm{a}$ & $2.79 \mathrm{a}$ \\
Leaf dry mass $(\mathrm{g})$ & $2.04 \mathrm{a}$ & $1.49 \mathrm{ab}$ & $1.37 \mathrm{ab}$ & $0.96 \mathrm{~b}$ \\
Shoot dry mass $(\mathrm{g})$ & $1.37 \mathrm{a}$ & $0.94 \mathrm{ab}$ & $0.81 \mathrm{bc}$ & $0.52 \mathrm{c}$ \\
Root dry mass $(\mathrm{g})$ & $0.33 \mathrm{a}$ & $0.21 \mathrm{ab}$ & $0.19 \mathrm{~b}$ & $0.18 \mathrm{~b}$ \\
Shoot water content $\left(\mathrm{g} \mathrm{g}^{-1} \mathrm{DM}\right)$ & $2.44 \mathrm{a}$ & $3.12 \mathrm{a}$ & $2.62 \mathrm{a}$ & $3.14 \mathrm{a}$ \\
Root water content $\left(\mathrm{g} \mathrm{g}^{-1} \mathrm{DM}\right)$ & $9.51 \mathrm{c}$ & $13.76 \mathrm{~b}$ & $14.35 \mathrm{ab}$ & $16.65 \mathrm{a}$ \\
\hline
\end{tabular}

Means followed by different letters are significantly different by the Tukey test $(P \leq 0.05)$. DM= dry mass

\section{Effect of salinity on biochemical parameters}

The level of protein of the soybean leaves was not altered significantly by salinity, compared to the control (Table 2). A strong decline in the nitrate content of the roots was found, in the presence of $\mathrm{NaCl}$. At the lowest salt concentration, $50 \mathrm{mM}$, a decrease of $72 \%$ was recorded, followed by $80 \%$ and $83 \%$ for the treatments using higher concentrations of salt $(100 \mathrm{mM}$ and $200 \mathrm{mM}$, respectively).

The level of total free amino acids in the root decreased for all salt concentrations tested (Table 2).

Table 2 - Soluble protein in leaves, free amino acids and nitrate in roots of soybean, after receiving complete nutrient solution with different $\mathrm{NaCl}$ concentrations.

\begin{tabular}{lcrrr}
\hline \multirow{2}{*}{ Analysis } & \multicolumn{4}{c}{ NaCl concentration $(\mathbf{m M})$} \\
\cline { 2 - 4 } & $\mathbf{0}$ & $\mathbf{5 0}$ & $\mathbf{1 0 0}$ & $\mathbf{2 0 0}$ \\
\hline Proteins $\left(\mathrm{mg} \mathrm{g}^{-1} \mathrm{FM}\right)$ & $32.55 \mathrm{a}$ & $29.07 \mathrm{a}$ & $33.76 \mathrm{a}$ & $29.92 \mathrm{a}$ \\
Nitrate $\left(\mu \mathrm{g} \mathrm{g}^{-1} \mathrm{FM}\right)$ & $48.56 \mathrm{a}$ & $13.56 \mathrm{~b}$ & $9.33 \mathrm{~b}$ & $8.11 \mathrm{~b}$ \\
Amino acids $\left(\mu \mathrm{mol} \mathrm{g}{ }^{-1} \mathrm{FM}\right)$ & $2.58 \mathrm{a}$ & $1.06 \mathrm{~b}$ & $0.75 \mathrm{~b}$ & $0.98 \mathrm{~b}$ \\
\hline
\end{tabular}

Means followed by different letters are significantly different by the Tukey test $(P \leq 0.05)$. FM= fresh mass. 
The amino acid composition of both the xylem bleeding sap and root tissue of the soybean plants under the different salt treatments is shown in Tables 3 and 4, respectively. In the control, Asn was the most abundant amino acid (88\%) in the xylem sap. Under the salt treatments there was a reduction in the proportion of Asn in the xylem sap and an increase in the other amino acids, especially for Ser, Ala, Gaba and Pro. In the control these amino acids were close to $1 \%$ of the total, but under salt treatment Ser and Ala reached $9 \%$ or more (Table 3 ).

In the roots, Asn was again the most prominent amino acid (79\%) and after treatment with salt it declined while Gaba showed the highest increase (Table 4).

Table 3 - Amino acid (AA) composition (mol \%) of the xylem sap of soybean, after receiving complete nutrient solution with different $\mathrm{NaCl}$ concentrations.

\begin{tabular}{lrrrr} 
& \multicolumn{4}{c}{ NaCl concentration $(\mathbf{m M})$} \\
\cline { 2 - 5 } AA $(\mathbf{m o l} \%)$ & $\mathbf{0}$ & $\mathbf{5 0}$ & $\mathbf{1 0 0}$ & $\mathbf{2 0 0}$ \\
\hline Asp & 1.12 & 2.25 & 3.62 & 1.49 \\
Asn & 88.84 & 60.41 & 57.53 & 60.26 \\
Ser & 0.87 & 9.21 & 8.96 & 5.12 \\
Ala & 0.70 & 9.20 & 9.40 & 11.25 \\
Gaba & 1.34 & 2.62 & 2.15 & 3.76 \\
Pro** & 0.74 & 3.52 & 7.72 & 4.68 \\
Others* & 6.39 & 12.79 & 10.62 & 13.44 \\
\hline
\end{tabular}

*All other amino acids (Glu, Gln, His, Gly, Thr, Arg, Tyr, Met, Val, Phe, Ile, Leu and Lys) that individually were less than 3\% in any treatment. Pro** was identified by derivatization with FMOC.

Table 4 - Amino acid (AA) composition of the roots of soybean, after receiving complete nutrient solution with different $\mathrm{NaCl}$ concentrations.

\begin{tabular}{lcrrr}
\hline \multirow{2}{*}{ AA $(\mathbf{m o l} \%)$} & \multicolumn{4}{c}{ NaCl concentration $(\mathbf{m M})$} \\
\cline { 2 - 5 } & $\mathbf{0}$ & $\mathbf{5 0}$ & $\mathbf{1 0 0}$ & $\mathbf{2 0 0}$ \\
\hline Asp & 1.81 & 6.26 & 3.13 & 2.73 \\
Glu & 2.88 & 5.96 & 3.28 & 3.12 \\
Asn & 79.39 & 51.61 & 65.34 & 67.68 \\
Ser & 1.61 & 4.32 & 3.38 & 4.25 \\
Gaba & 4.76 & 16.51 & 11.92 & 8.58 \\
Others* & 9.55 & 15.34 & 12.95 & 13.64 \\
\hline
\end{tabular}

*All other amino acids (Gln, His, Gly, Thr, Arg, Tyr, Ala, Met, Val, Phe, Ile, Leu and Lys) that individually were less than 3\% in any treatment.

\section{DISCUSSION}

Although salt stress can provoke several metabolic alterations in plants such as the peroxidation of lipids, reduction in chlorophyll content, increase in ROS and anti-oxidative enzyme activity (Monteiro et al. 2011), all such alterations are accompanied by reduced plant growth. The evaluation of the sensitivity of plants to stress is, quite often, based on data for plant growth (Ahmad et al. 2007; Koca et al. 2007; Ulfat et al. 2007; Zheng et al. 2008; Karlidag et al. 2009; Campestre et al. 2011). Flowers and Hajibagheri (2001) and Qian et al. (2004; 2007) reported that the maintenance of normal root growth under salinity demonstrates that a plant is tolerant to salt. However, it is possible that the maintenance of root growth under such conditions was due to the adaptation of the plant to salt stress rather than tolerance strictly speaking. In this study, an analysis of the growth parameters revealed that soybean roots were less affected by salt than the shoot. The length of the roots and the fresh weight were not reduced significantly by increasing concentrations of salt. Water content of the roots, based on dry weight, increased under salinity. The accumulation of water in the cell has been related to greater tolerance to salt stress (Greenway and Munns 1980; Costa et al. 2003), since, as a result, the plant would be able to diminish the concentration of salts in the cytoplasm (Ghoulam et al. 2002), thereby avoiding the interference of $\mathrm{Na}^{+}$with cellular functions (Tester and Davenport 2003). 
The reduction in leaf area found not only in this study but for other species subjected to salt stress (Silveira et al. 2003; Tabatabaei 2006, Zheng et al. 2008) could be seen as an adaptation to limit transpiration (Neumann 1997). This reduction could be the result of ion accumulation in the leaves, which accelerates their abscission (Tester and Davenport 2003; Tabatabaei 2006). It could also be caused by the reduction in leaf expansion, as a result of the fall in turgor pressure (Marcelis and Hooijdonk 1999), since under salt stress water uptake by the plant would be impaired (Umezawa et al. 2002; Carillo et al. 2005).

Salinity led to decreases in the dry weights of the soybean plants in this study which coincides with similar data reported for this (El-Samad and Shaddad 1997; Liu and Staden 2001) as well as several other species (Costa et al. 2003; Silveira et al. 2003; Kaya et al. 2007). The reduction in dry mass could be explained by reduced photosynthesis, in view of the diminished leaf area and availability of nutrients (Marcelis and Hooijdonk 1999), such as the reduction in nitrate uptake observed in this study.

The diminished fresh weight of the aerial part of the soybean plants could have arisen as a consequence of the lower water potential, due to elevated concentrations of salt in the external medium (Marcelis and Hooijdonk 1999).

The stability of proteins found in this study was also observed by Costa et al. (2003) in leaves of cowpea plants cultivated under salinity. Although proteolysis can increase under salt stress (Silveira et al. 2003), there are proteins that are specifically synthesized under stress conditions (Bouché et al. 2005; Parker et al. 2006; Younis et al. 2009). It is possible that protein levels did not alter due to a compensating increase in the synthesis of such stress-specific proteins. A comparative study of protein profiles in the presence and absence of salt should help to clarify this point.

The reduction in the concentration of nitrate observed in the roots was also reported for cashew (Silveira et al. 2003) and cowpea (Silveira et al. 2001). This reduction could be due to a reduced uptake of nitrate as a result of the interference of the $\mathrm{Cl}^{-}$ion on certain systems of membrane transport (Silveira et al. 2001; Rubinigg et al. 2003). According to Carillo et al. (2005), the $\mathrm{Cl}^{-}$ ion competes with nitrate for the binding site of the transporter. The fall in root amino acid concentration found in this study has also been reported for cowpea (Costa et al. 2003) and may well be related to the reduced uptake of nitrate by the roots (Rubinigg et al. 2003; Carillo et al., 2005) leading to lower assimilation of nitrogen and consequently synthesis of amino acids (Silveira et al. 2001; Flores et al. 2002).

According to Amarante and Sodek (2006) changes in the amino acid composition in the xylem appear to be useful indicators of changes in root $\mathrm{N}$ metabolism and may reflect changes in dynamic aspects of this metabolism not always seen when simply measuring the amino acid composition of the root. Asn is the most abundant amino acid found in the xylem sap of non-nodulated soybean (McClure and Israel 1979). The present data show a reduction in this amino acid under salt treatment. Puiatti and Sodek (1999), Souza and Sodek (2003) and Thomas and Sodek (2006) observed a reduction in the abundance of Asn in the xylem sap of soybean plants cultivated with nitrate and subjected to hypoxia and discussed the possibility that the reduction might involve conversion of this amino acid (or its precursor, Asp) to Ala (see Fig. 1). The reduction in Asn in function of stress occurs in several situations and appears to involve a decline in the activity of asparagine synthetase, responsible for the transformation of Asp to Asn (Lima and Sodek 2003; Antunes et al. 2008). Often, but certainly not always, the reduction in xylem Asn is accompanied by a concomitant increase in Asp (Lima and Sodek 2003). When an increase in Asp is not evident, as in the present study with salt stress, it is possible that Asp was rapidly metabolized to products other than Asn, as shown in Figure1. According to that scheme, two such products are Ala and Gaba, the two amino acids that showed a substantial increase in the salt treatment, concomitant with the decline in Asn. The synthesis of Gaba occurs by $\alpha$ decarboxylation of Glu, a reaction that consumes protons and consequently helps stabilize the $\mathrm{pH}$ of the cell (Crawford et al. 1994). Although Glu did not increase significantly under salinity, it may well be that its turnover increased but its concentration was maintained through dynamic equilibrium between synthesis from Asn/Asp and transformation to Gaba and Ala (Fig. 1). On the other hand, GABA might have accumulated through polyamine degradation, as observed in roots of the soybean cultivar Suxie-1, grown under salt stress (Xing et al. 2007). Further studies are required before any conclusion can be drawn regarding GABA accumulation. 


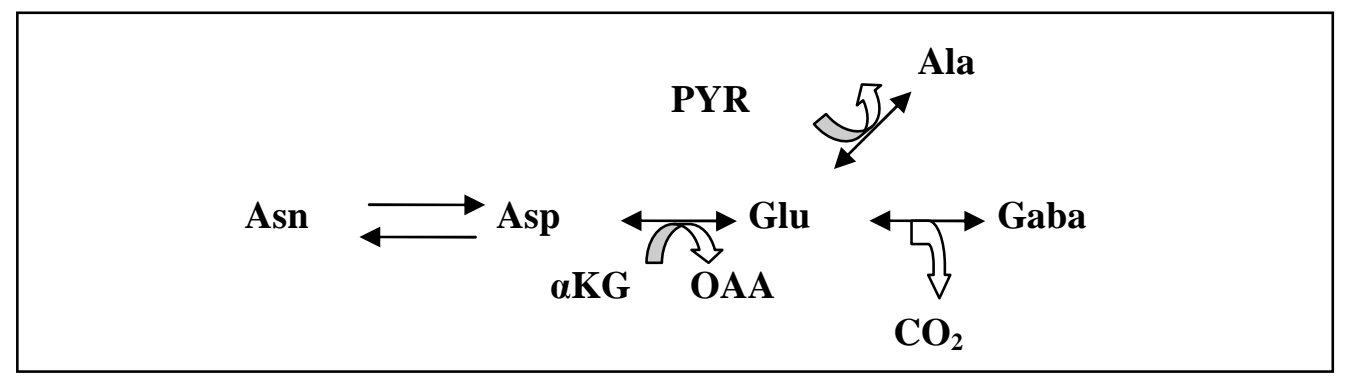

Figure 1 - Scheme showing alanine (Ala) and $\gamma$-aminobutyrate (Gaba) synthesis from asparagine. (Asn). Asp = aspartate; $\alpha \mathrm{KG}=\alpha$-ketoglutarate; OAA = oxaloacetic acid; Glu $=$ glutamate; Pyr = pyruvate.

Besides Gaba and Ala there was a perceptible increase in Pro and Ser in the xylem sap under salinity, which could be related to the observation that these amino acids are associated with abiotic stresses (Bouché et al. 2003; Souza and Sodek 2003; Ashraf and Harris 2004; Yazici et al. 2007). There is still controversy over the role of Pro in salt stress tolerance. While several authors regard Pro accumulation as a stress adaptation factor, others suggest it as a consequence of stress (see reviews by Ashraf and Harris 2004; Ashraf and Foolad 2007). When Pro content was measured in the leaves of two soybean cultivars with different sensitivities to salt stress, higher accumulation occurred in the most sensitive cultivar, leading to the conclusion that at least in that case the accumulation of Pro had no adaptive role towards salt stress (Moftah and Michel 1987). Another study with soybean and sorghum revealed that under saline stress the accumulation of Pro occurred only after the plants had become severely stressed (Waldren and Teare 1974). However, there are several reports of plant species showing that high concentrations of Pro are associated with considerable resistance to salinity (Misra and Gupta 2005; Ashraf and Orooj 2006; Ahmad et al. 2007; Koca et al. 2007; Yazici et al. 2007, Meloni et al. 2008). A recent review on the subject (Szabados and Savoré 2009) suggests that Pro accumulation is not an absolute requirement for adaptation to stress conditions but rather it is the metabolism of the amino acid that is important as a mechanism for plant homeostasis under stress. Since stress leads to a reduction in Calvin cycle activity, NADPH turnover will be slow which, under high light, will favor ROS accumulation. Pro biosynthesis in the chloroplast will consume NADPH and increase $\mathrm{NADP}^{+}$regeneration allowing increased electron chain activity and thereby reduce photoinhibition and damage of the photosynthetic apparatus at higher light intensities. The authors also suggest that catabolism of the accumulated Pro after stress is important in providing energy for resumed growth through the generation of NADH and $\mathrm{FADH}_{2}$ for mitochondrial respiration. Evidently more detailed studies of plant metabolism that go beyond the measurement of Pro levels are required to explain the role of Pro in salt stress.

\section{CONCLUSION}

The growth of roots of the soybean cultivar IAC 17 was less affected by salinity than the aerial part and the content of water in the roots increased under this condition. Leaf area diminished in the presence of salt. These factors together can contribute to the adaptation of the plant, improving its hydration. Salinity led to alterations in the composition of the amino acids transported in the xylem, with increases in amino acids characteristically related to stress, such as Pro and Gaba, which can contribute to the adaptation of the plant to salinity.

\section{ACKNOWLEDGEMENTS}

H. M. Queiroz is grateful to the Lanagro for financial support.

\section{REFERENCES}

Ahmad MSA, Javed F, Asharf, M. Iso-osmotic effect of $\mathrm{NaCl}$ and PEG on growth, cations and free proline accumulation in callus tissue of two indica rice (Oriza 
sativa L.) genotypes. Plant Growth Regul. 2007; 53: 53-63.

Alshamary SF, Qian YL, Wallner SJ. Growth response of four turfgrass species to salinity. Agr. Water Manag. 2004; 66: 97-111.

Amarante L, Sodek, L. Waterlogging effect on xylem sap glutamine of nodulated soybean. Biol. Plant. 2006; 50: 405-410.

An P, Inaga S, Kafkafi U, Lux A, Sugimoto Y. Different effect of humidity on growth and salt tolerance of two soybean cultivars. Biol. Plant. 2001; 44: 405-410.

Antunes F, Sodek L, Pineda M, Aguilar M. Nitrogen stress and the expression of asparagine synthetase in roots and nodules of soybean (Glycine max). Physiol. Plant. 2008; 133: 736-743.

Ashraf M, Foolad MR. Roles of glycine betaine and proline in improving plant abiotic stress resistance. Environ. Exp. Bot. 2007; 59: 206-216.

Ashraf M, Harris PJC. Potential biochemical indicators of salinity tolerance in plants. Plant Sci. 2004; 166: 316.

Ashraf M, Orooj A. Salt stress effects on growth, ion accumulation and seed oil concentration in an arid zone traditional medicinal plant ajwain (Trachyspermum ammi [L.] Sprague). J. Arid Environ. 2006; 64: 209-220.

Blanco FF, Folegatti MV, Gheyi HR, Fernandes PD. Growth and yield of corn irrigated with saline water. Sci. Agr. 2008; 65: 574-580.

Bolarín MC, Santa-Cruz A, Cayuela E, Pérez-Alfocea F. Short-term solute changes in leaves and roots of cultivated and wild tomato seedlings under salinity. $J$. Plant Physiol. 1995; 147: 463-468.

Bouché N, Aaron F, Bouchez D, Moller SG, Fromm H. Mitochondrial succinic-semialdehyde dehydrogenase of the $\gamma$-aminobutyrate shunt is required to restrict levels of reactive oxygen intermediates in plants. Proc. Natl. Acad. Sci. U. S. A. 2003; 100: 6843-6848.

Bouché N, Yellin A, Snedden WA Fromm H. Plantspecific calmodulin-binding proteins. Annu. Rev. Plant Biol. 2005; 56: 435-466.

Bradford MM. A rapid and sensitive method for the quantitation of microgram quantities of protein utilizing the principle of protein-dye binding. Anal. Biochem. 1976; 72: 248-254.

Campestre MP, Bordenave CD, Origone AC, Menéndez $\mathrm{AB}$, Ruiz AO, Rodríguez AA, et al. Polyamine catabolism is involved in response to salt stress in soybean hypocotils. J. Plant Physiol. 2011; 168: 1234-1240.

Carillo P, Mastrolonardo G, Nacca F, Fuggi A. Nitrate reductase in durum wheat seedlings as affected by nitrate nutrition and salinity. Funct. Plant Biol. 2005; 32: 209-219.
Cataldo DA, Haroon M, Schrader LE, Youngs VL. Rapid colorimetric determination of nitrate in plant tissues by nitration of salicilic acid. Commun. Soil Sci. Plant Anal. 1975; 6: 71-80.

Costa PHA, Silva JV, Bezerra MA, Enéas Filho J, Prisco JT, Gomes Filho E. Crescimento e níveis de solutos orgânicos e inorgânicos em cultivares de Vigna unguiculata submetidos à salinidade. Rev. Bras. Bot. 2003; 26: 289-297.

Crawford LA, Brown AW, Breitkreuz KE, Guinel FC. The synthesis of $\gamma$-aminobutyric acid in response to treatments reducing cytosolic $\mathrm{pH}$. Plant Phisiol. 1994; 104: 865-871.

Demir I, Mazi K. Effect of salt and osmotic stresses on the germination of pepper seeds of different maturation stages. Braz. Arch. Biol. Technol. 2008; 51: 897-902.

Dutilleul C, Garmier M, Noctor G, Mathieu C, Chétrit $\mathrm{P}$, Foyer $\mathrm{CH}$ et al. Leaf mitochondria modulate whole cell redox homeostasis, set antioxidant capacity, and determine stress resistance through altered signaling and diurnal regulation. Plant Cell. 2003; 15: 12121226.

El-Samad HMA, Shaddad MKA. Salt tolerance of soybean cultivars. Biol. Plant. 1997; 39: 263-269.

FAO. Global network on integrated soil management for sustainable use of salt affected soils. [Internet]. 2000 [accessed in 2008 Dec. 22]. Available from: http://www.fao.org/ag/AGL/agll/spush/intro.htm.

Fehr WR, Caviness CE, Burmood DT, Pennington JS. Stage of development descriptions for soybeans, Glycine $\max ($ L.). Crop Sci. 1971; 11: 929-931.

Flores P, Botella MA, Martinez V, Cerda A. Response to salinity of tomato seedlings with a split-root system: nitrate uptake and reduction. J. Plant Nutr. 2002; 25: 177-187.

Flowers TJ, Hajibagheri MA. Salinity tolerance in Hordeum vulgare: ion concentrations in root cells of cultivars differing in salt tolerance. Plant Soil. 2001; 231: $1-9$.

Foyer $\mathrm{CH}$, Noctor G. Oxidant and antioxidant signaling in plants: a re-evaluation of the concept of oxidative stress in a physiological context. Plant Cell Environ. 2005a; 28: 1056-1071.

Foyer CH, Noctor G. Redox homeostasis and antioxidant signaling: a metabolic interface between stress perception and physiological responses. Plant Cell. 2005b; 17: 1866-1875.

Galvan-Ampudia CS, Testerink C. Salt stress signals shape the plant root. Curr. Opin. Plant Biol. 2011; 14: 296-302.

Ghoulam C, Foursy A, Fares K. Effects of salt stress on growth, inorganic ions and proline accumulation in relation to osmotic adjustment in five sugar beet cultivars. Environ. Exp. Bot. 2002; 47: 39-50. 
Gomes-Júnior RA, Gratão PL, Gaziola AS, Mazzafera P, Lea, PJ, Azevedo RA. Selenium-induced oxidative stress in coffee cell suspension cultures. Funct. Plant Biol. 2007; 34: 449-456.

Gratão PL, Polle A, Lea PJ, Azevedo RA. Making the life of heavy metal-stressed plants a little easier. Funct. Plant Biol. 2005; 32: 481-494.

Greenway H, Munns R. Mechanisms of salt tolerance in nonhalophytes. Annu. Rev. Plant Physiol. 1980; 31: 49-90.

Hasegawa PM, Bressan RA, Zhu JK, Hnert HJ. Plant cellular and molecular responses to high salinity. Annu. Rev. Plant Physiol. Plant Molec. Biol. 2000; 51: 463-499.

Hoagland DR, Arnon DI. The water culture method for growing plants without soil. Davis: University of California Agricultural Experimental Station 1938; (Bulletin, 347).

Karlidag H, Yildirim E, Turam M. Salicylic acid ameliorates the adverse effect of salt stress on strawberry. Sci. Agr. 2009; 66: 180-187.

Kaya C, Tuna AL, Ashraf M, Altunlu H. Improved salt tolerance of melon (Cucumis melo L.) by the addition of proline and potassium nitrate. Environ. Exp. Bot. 2007; 60: 397-403.

Koca H, Bor M, Özdemir F, Türkan I. The effect of salt stress on lipid peroxidation, antioxidative enzymes and proline content of sesame cultivars. Environ. Exp. Bot. 2007; 60: 344-351.

Lee GJ, Boerma HR, Villagarcia MR, Zhou X, Carter TE, Li Z, et al. A major QTL conditioning salt tolerance in S-100 soybean and descendent cultivars. Theor. Appl. Genet. 2004; 109: 1610-1619.

Lima JD, Sodek L. N-stress alters aspartate and asparagine levels of xylem sap in soybean. Plant Sci. 2003; 165: 649-656.

Liu T, and Staden J. Growth rate, water relations and ion accumulation of soybean callus lines differing in salinity tolerance under salinity stress and its subsequent relief. Plant Growth Regul. 2001; 34: 277-285.

Maaroufi-Dguimi H, Debouba M, Gaufichon L, Clément G, Gouia H,. Hajjaji A. et al. An Arabidopsis mutant disrupted in ASN2 encoding asparagine synthetase 2 exhibits low salt stress tolerance. Plant Physiol. Biochem. 2011; 49: 623628.

Marcelis LFM, Hooijdonk J. Effect of salinity on growth, water use and nutrient use in radish (Raphanus sativus L.). Plant Soil. 1999; 215: 57-64.

Marur CJ, Sodek L, Magalhães ACN. Free amino acids in leaves of cotton plants under water deficit. Rev. Brasil. Fisiol. Veg. 1994; 6: 103-108.

McClure PR, Israel DW. Transport of nitrogen in the xylem of soybean plants. Plant Physiol. 1979; 64: 411-416.
Meloni DA, Gulotta MR, Martínez CA. Salinity tolerance in Schinopsis quebracho colorado: seed germination, growth, ion relations and metabolic responses. J. Arid Environ. 2008; 72: 1785-1792.

Mhamdi A, Mauve C, Gouia G, Saindrenan P, Hodeges M, Noctor G. Cytosolic NADP-dependent isocitrate dehydrogenase contributes to redox homeostasis and the regulation of pathogen responses in Arabidopsis leaves. Plant Cell Environ. 2010; 33: 1112-1123.

Misra AN, Gupta KA. Effect of salt stress on proline metabolism in two high yielding genotypes of green gram. Plant Sci. 2005; 169: 331-339.

Moftah AE, Michel BE. The effect of sodium chloride on solute potential and proline accumulation in soybean leaves. Plant Physiol. 1987; 83: 238-240.

Monteiro CC, Carvalho RF, Gratão PL, Carvalho G, Tezotto T, Médici LO, et al. Biochemical responses of the ethylene-insensitive Never ripe tomato mutant subjected to cadmium and sodium stresses. Environ. Exp. Bot. 2011; 71: 306-320.

Nasholm T, Sanberg G, Ericson A. Quantitative analysis of amino acids in conifer tissues by highperformance liquid chromatography and fluorescence detection of their 9-fluorenylmethyl-chloroformate derivatives. J. Chromatogr. 1987; 396: 225-236.

Neto EB, Nogueira RJMC. Compatative study of tomato and maize plant growth under different salt conditions. Braz. Arch. Biol. Technol. 1999; 42: 471475.

Neumann P. Salinity resistance and plant growth revisited. Plant Cell Environ. 1997; 20: 1193-1198.

Noctor G. Metabolic signaling in defence and stress: the central roles of soluble redox couples. Plant Cell Environ. 2006; 29: 409-425.

Okusanya OT. Effect of sea water and temperature on germination behavior of Crithmum maritimumm. Physiol. Plant. 1977; 41: 265-267.

Parker R, Flowers TJ, Moore AL, Harpham NVJ. An accurate and reproducible method for proteome profiling of the effects of salt stress in the rice leaf lamina. J. Exp. Bot. 2006; 57: 1109-1118.

Puiatti M, Sodek L. Waterlogging affects nitrogen transport in the xylem of soybean. Plant Physiol. Biochem. 1999; 37: 767-773.

Qian YL, Follett RF, Wilhelm S, Loski AJ, Shahba MA. Carbon isotope discrimination of three Kentucky bluegrass cultivars with contrasting salinity tolerance. Agron. J. 2004; 96: 571-575.

Qian YL, Fu JM, Wilhelm S, Christensen D, Koski, AJ. Relative salinity tolerance of turf-type saltgrass selections. Hortscience. 2007; 42: 205-209.

Qu C, Liu C, Ze Y, Gong X, Hong M, Wang L, et al. Inhibition of nitrogen and photosynthetic carbon assimilation of maize seedlings by exposure to a combination of salt stress and potassium-deficient stress. Biol. Trace Elem. Res. 2011; 144: 1159-1174. 
Queval G, Jaillard D, Zechmann B, Noctor G. Increased intracellular $\mathrm{H}_{2} \mathrm{O}_{2}$ availability preferentially drives glutathione accumulation in vacuoles and chloroplasts. Plant Cell Environ. 2011; 34: 21-32.

Renault H, Roussel V, El Amrani A, Arzel M, Renault $\mathrm{D}$, Bouchereau A, et al. The Arabidopsis pop2-1 mutant reveals the involvement of GABA transaminase in salt stress tolerance. BMC Plant Biol. 2010; 10: 20 (on line).

Rubnigg M, Posthumus F, Ferschke M, Theo J, Elzenga M, Stulen I. Effects of $\mathrm{NaCl}$ salinity on ${ }^{15} \mathrm{~N}$-nitrate fluxes and specific root length in the halophyte Plantago maritima L. Plant Soil. 2003; 250: 201-213.

Silveira JAG, Melo ARB, Viégas RA, Oliveira, JTA. Salinity-induced effects on nitrogen assimilation related to growth in cowpea plants. Environ. Exp. Bot. 2001; 46: 171-179.

Silveira JAG, Viégas RD, Rocha IMA, Moreira ACDM, Moreira RD, Oliveira JTA. Proline accumulation and glutamine synthetase activity are increased by salt-induced proteolysis in cashew leaves. J. Plant Physiol. 2003; 160: 115-123.

Souza CAF, Sodek L. Alanine metabolism and alanine aminotransferase activity in soybean (Glycine max) during hypoxia of the root system and subsequent return to normoxia. Environ. Exp. Bot. 2003; 50: 1-8.

Surabhi G-K, Reddy AM, Kumasi GJ, Sudhakar C. Modulations in key enzymes of nitrogen metabolism in two high yielding genotypes of mulberry (Morus alba L.) with differential sensitivity to salt stress. Environ. Exp. Bot. 2008; 64: 171-179.

Szabados L, Savouré A. Proline: a multifunctional amino acid. Trends Plant Sci. 2009; 15: 89-97.

Tabatabaei SJ. Effects of salinity and N on the growth, photosynthesis and $\mathrm{N}$ status of olive (Olea europaea L.) trees. Sci. Hortic. 2006; 25: 432-438.

Tester M, Davenport R. Na ${ }^{+}$tolerance and $\mathrm{Na}^{+}$transport in higher plants. Ann. Bot. 2003; 91: 503-527.

Thomas AL, Sodek L. Amino acid and ureide transport in the xylem of symbiotic soybean plants during short-term flooding of the root system in the presence of different sources of nitrogen. Braz. J. Plant Physiol. 2006; 18: 333-339.

Türkan I, Demiral T. Recent developments in understanding salinity tolerance. Environ. Exp. Bot. 2009; 67: 2-9.

Ulfat M, Athar HUR, Ashraf M, Akram NA, Jamil A. Appraisal of physiological and biochemical selection criteria for evaluation of salt tolerance in canola (Brassica napus L.). Pak. J. Bot. 2007; 39: 15931608.
Umezawa T, Mizuno K, Fujimura T. Discrimination of genes expressed in response to the ionic or osmotic effect of salt stress in soybean with cDNA-AFL. Plant Cell Environ. 2002; 25: 1617-1625.

USDA. Production Estimates and Crop Assessment Division, Foreign Agricultural Service, Brazil: 2005/2006 soybean area projected to decline. [Internet]. [accessed in 2008 Dec. 27]. Available from:http://www.fas.usda.gov/pecad/highlights/2005/ 09/Brazil_12Sep2005/index.htm.

Vicente O, Boscaiu M, Naranjo MA, Estrelles E, Belles JM, Soriano P. Responses to salt stress in the halophyte Plantago crassifolia (Plantaginaceae). J. Arid Environ. 2004; 58: 463-481.

Waldren RP, Teare ID. Free proline accumulation in drought-stressed plants under laboratory conditions. Plant Soil. 1974; 40: 689-692.

Xing SG, Jun YB, Hau ZW, Liang LY. Higher accumulation of $\gamma$-aminobutyric acid induced by salt stress through stimulating the activity of diamine oxidases in Glycine max (L.) Merr. Roots. Plant Physiol. Biochem. 2007; 45: 560-566.

Yazici I, Türkan I, Sekmen AH, Demiral T. Salinity tolerance of purslane (Portulaca oleraceae L.) is achieved by enhanced antioxidative system, lower level of lipid peroxidation and proline accumulation. Environ. Exp. Bot. 2007; 61: 49-57.

Yemm EW, Cocking EC. The determination of amino acids with ninhydrin. Analyst. 1955; 80: 09-213.

Younis ME, Hasaneen MN, Kazamel AMS. Plant growth, metabolism and adaptation to stress conditions. XXVII. Can ascorbic acid modify the adverse effects of $\mathrm{NaCl}$ and manitol on amino acids, nucleic acids and protein patterns in Vicia faba seedlings? Protoplasma. 2009; 235: 37-47.

Zheng Y, Wang Z, Sun X, Jia A, Jiang G, Li Z. Higher salinity tolerance cultivars of winter wheat relieved senescence at reproductive stage. Environ. Exp. Bot. 2008; 62: 129-138. 
PAGINA EM BRANCO 